\title{
Comparação de caracteres morfológicos e agronômicos com moleculares em morangueiros cultivados no Brasil
}

\author{
José Henrique Conti; Keigo Minami; Flavio Cesar Almeida Tavares \\ ESALQ, C. Postal 09, 13.418-900 Piracicaba - SP. E-mail: jhconti@hiway.com.br
}

\begin{abstract}
RESUMO
Caracteres morfológicos (forma dos dentes, ângulo da base e razão entre o comprimento e a largura do folíolo, cor da folha, posição da inflorescência em relação à folhagem e tamanho do cálice em relação ao fruto), agronômicos (grau de proteção da inflorescência pelas folhas, presença de "pescoço" no fruto, produção, número e peso médio de frutos, teor de sólidos solúveis, $\mathrm{pH}$, textura e cor externa e interna) e moleculares foram estudados em cultivares do morangueiro, para verificar se os dados morfológicos e agronômicos apresentam correlação com os moleculares. Dados experimentais foram obtidos em campo em Atibaia (SP) e Piracicaba (SP), em 1996, no delineamento em blocos ao acaso, com quatro repetições e dezesseis plantas por parcela das cultivares Campinas, Dover, Guarani, Princesa Isabel e AGF 080. Para a caracterização molecular utilizou-se o método do polimorfismo de DNA amplificado ao acaso (RAPD). Os resultados da análise de similaridade entre as cultivares foram equivalentes, quando utilizadas características morfológicas e agronômicas ou moleculares, indicando que os métodos de caracterização tiveram o mesmo poder de resolução na distinção das cultivares. A 'AGF 080' não dispõe de registros de origem, mas não foi possível distinguí-la da 'Campinas', pelos métodos utilizados. A cultivar Princesa Isabel tem origem semelhante à 'Guarani'; no entanto suas características morfológicas, agronômicas e moleculares foram mais semelhantes com as da 'Dover', que não tem relações de origem com 'Princesa Isabel'.
\end{abstract}

Palavras-chave: Fragaria $x$ ananassa Duch., RAPD, similaridade genética, caracteres morfo-agronômicos.

\begin{abstract}
Comparison of morphological and agricultural characters with molecular ones in Brazilian strawberries

The morphological (form of teeth, angle of the base, and ratio between length and width of leaves, color of leaves, inflorescence position regarding the canopy, calyx size related to the fruit and immature fruit color), agricultural (degree of protection of inflorescence to the leaves and the characteristics of neck presence in fruits, production, number and average weight, amount of soluble solids, $\mathrm{pH}$, texture and external and internal color) and molecular characteristics of strawberries were studied, to identify correlation between morphological and agricultural data to the molecular ones. Field data were collected in Atibaia and Piracicaba (São Paulo State), in 1996. Experimental design was of randomized blocks with four replications and sixteen plants per plot using the cultivars Campinas, Dover, Guarani, Princesa Isabel and AGF 080. The molecular characterization was obtained through the method of Random Amplified Polymorphic DNA (RAPD). The results of the similarity analysis among cultivars were equivalent, when morphological and agricultural or molecular characteristics were evaluated, indicating that the methods presented the same resolution power to distinguish cultivars. In spite of the unknown origin of 'AGF 080', it was not possible to distinguish it from the 'Campinas' using the method employed. Although Princesa Isabel's origin is similar to 'Guarani', the morphological, agricultural and molecular characteristics presented more similarity to 'Dover' which has no origin relationship with 'Princesa Isabel'.
\end{abstract}

Keywords: Fragaria Xananassa Duch., RAPD, genetic similarity, morpho-agronomic traits.

(Recebido para publicação em 25 de fevereiro de 1999 e aceito em 15 de março de 2002)

$\mathrm{O}$ morangueiro é produzido em diversas regiões e tipos de clima, desde zonas temperada, mediterrânea, subtropical até zonas de taiga. A espécie cultivada, Fragaria Xananassa Duch., um híbrido originário da América, proveniente das espécies Fragaria virginiana e Fragaria chiloensis, se desenvolve em todo o mundo, mas populações naturais desta espécie são restritas à costa da California e aos Estados de Oregon e Washington, EUA (Hancock \& Luby, 1993).

Além do melhoramento ter provocado o estreitamento da base genética do morangueiro cultivado (Sjulin \& Dale, 1987), a maioria das cultivares originou-se de poucos ancestrais (Scott \& Lawrence, 1975). O sucesso no desenvolvimento de novas combinações de caracteres pode ser limitado pois atualmente não se conhece a diversidade do germoplasma disponível em programas de melhoramento e as informações de origem não são elucidativas quanto à diversidade genética, podendo ocorrer cultivares diferentes geneticamente, mas com nomes semelhantes (Graham et al. 1996).

No Brasil, a cultura do morangueiro teve grande expansão a partir da década de 60 , devido à aceitabilidade da cultivar Campinas (Passos, 1997) e à introdução de novas técnicas de cultivo.
Atualmente, a ocorrência de antracnose ("flor preta") e a expansão da cultura para áreas distantes dos mercados consumidores tem estimulado o produtor a buscar novas técnicas de cultivo e novas cultivares. Contudo, na utilização destas novas formas, é imprescindível caracterizá-las, como meio de se evitar o cultivo de germoplasma com constituições genômicas semelhantes, embora com denominações diferentes. Adicionalmente, a caracterização genética constitui a base para trabalhos de estimativas de similaridade genética.

A caracterização de cultivares pode se basear nas diferenças de morfologia da folha, da planta ou do fruto ou das 
moléculas de proteínas ou de DNA, as quais são comumente denominadas de diferenças moleculares. No Brasil, o registro institucional de cultivares de morangueiro baseia-se no trabalho de Passos et al. (1994) onde são descritas as características morfológicas que devem ser consideradas na caracterização de cultivares. A caracterização molecular por análise de proteínas (isoenzimas) é interessante na cultura do morangueiro. No entanto, os trabalhos de Nehra et al. (1991) e Bringhurst et al. (1981), demonstraram que o número de possíveis "marcadores" é pequeno. Proposta por Williams et al. (1990), a técnica de Polimorfismo de DNA Amplificado ao Acaso (RAPD) demonstrou ser eficiente na identificação de cultivares do morangueiro nos trabalhos de Parent \& Pagé (1995); Gidoni et al. (1994) e Graham et al. (1996).

A decisão de qual método utilizar depende dos recursos disponíveis e do grau de confiabilidade do método. A comparação entre métodos de caracterização é uma maneira de estimar o poder de resolução de cada um. Com dados morfológicos e agronômicos ou com moleculares é possível estimar o grau de similaridade entre cultivares. A comparação dos dados de similaridade obtidos permite determinar a possibilidade de uso dos métodos de caracterização. Com a finalidade de verificar a viabilidade de aplicação da caracterização molecular, via RAPD, em morangueiros, em relação à caracterização morfológica atualmente utilizada, foi proposto o presente trabalho.

\section{MATERIAL E MÉTODOS}

Os dados das características morfológicas e agronômicas foram obtidos em experimentos de campo em Atibaia (SP), em área de produção comercial de frutos e em Piracicaba (SP), em área do Departamento de Horticultura da ESALQ/USP, em 1996, no delineamento de blocos ao acaso, com quatro repetições e dezesseis plantas por parcela com as cultivares Campinas, Dover, Guarani, Princesa Isabel e AGF 080. Foram obtidas características moleculares em laboratório, utilizando folhas não expandidas destas culti- vares, cultivadas em vasos. A cultivar Campinas IAC 2712 foi desenvolvida em 1955 pelo IAC, após cruzamento dos clones Doner e Tahoe (Camargo, 1960). A cultivar Dover, desenvolvido na Universidade da Flórida (EUA), foi selecionada para a característica de resistência a antracnose nas condições da Flórida, resultado do cruzamento realizado em 1973 entre a cultivar Florida Belle e o clone Fla. 71-189 (Howard \& Albregts, 1980). As cultivares Guarani IAC 5074 e IAC Princesa Isabel foram desenvolvidas pelo engenheiro agrônomo Francisco Antonio Passos [a primeira corresponde ao 'seedling' número 13, selecionado da progênie do cruzamento realizado em 1974 entre as cultivares (Campinas x Monte Alegre) x Alemanha e a segunda foi selecionada do cruzamento realizado em 1981 entre as cultivares Alemanha e IAC Jundiai] (Camargo \& Passos, 1993). A 'AGF 080' foi desenvolvida pela empresa Agroflora Reflorestamento e Agropecuária S/A.

Camargo (1963) explica que a parte comestível, carnosa e suculenta do morango é um receptáculo dos verdadeiros frutos que são os aquênios, pequeninos, duros e superficiais. Entretanto, para fins comerciais, denominase fruto ao conjunto do receptáculo carnoso mais os aquênios, nomenclatura adotada neste trabalho. As características analisadas podem ser separadas em dois grupos, aquelas que se referem à morfologia da planta, da folha ou do fruto e aquelas que são de interesse agronômico. As características analisadas, bem como a metodologia utilizada estão citados na Tabela 1.

Para a extração do DNA, utilizado no estudo dos caracteres moleculares, em cada cultivar, foram coletadas duas folhas "não expandidas". A estas foi adicionado nitrogênio líquido e em seguida maceradas até a formação de um pó bem fino. Este material foi colocado em tubo de Eppendorf, onde foi adicionado tampão de extração $(3 \% \mathrm{CTAB}$, 1,4 M NaCl, 20 mM EDTA, $100 \mathrm{mM}$ Tris $\mathrm{Hcl} \quad \mathrm{pH} \quad 8,0, \quad 1 \%$ polivinilpirrolidone). $\mathrm{O}$ tubo foi incubado em banho Maria e em seguida foi adicionada solução de clorofórmioalcool isoamílico (24:1), após foi agita- do e centrifugado. Os ácidos nucleicos foram, então, precipitados através da adição de acetato de amônia $5 \mathrm{M}$ e etanol e depois ressuspenso em tampão TE (10 $\mathrm{mM}$ Tris $\mathrm{HCl}$ pH 8,0 e 1,0 mM EDTA), até ficar completamente dissolvido. Em seguida procedeu-se ao tratamento com RNAse e quantificação das amostras de DNA por espectrofotometria.

As amplificações foram feitas em volume de $25 \mathrm{ml}$ contendo $20 \mathrm{mM}$ de Tris $\mathrm{Hcl} \mathrm{pH} \mathrm{8,4,} 50 \mathrm{mM}$ de $\mathrm{KCl}, 100$ $\mathrm{mM}$ de cada um dos 4 desoxinucleotídeos, 20 ng de "primer" (10 pares de bases), $0,1 \%$ Triton X-100, 1,8 $\mathrm{mM}$ de $\mathrm{MgCl}_{2}, 25 \mathrm{ng}$ de DNA, 1,5 $\mathrm{U}$ da enzima Taq DNA Polimerase e 8,6 $\mathrm{ml}$ de água Milli $\mathrm{Q}$ estéril. A reação de amplificação foi feita em termociclador. O programa inicia-se com uma prédenaturação a $92^{\circ} \mathrm{C}$, por 2 minutos, seguida de 45 ciclos de 45 segundos a $94^{\circ} \mathrm{C}, 1$ minuto a $42^{\circ} \mathrm{C}$ e 2 minutos a $72^{\circ} \mathrm{C}$, com uma extensão final de $2 \mathrm{mi}-$ nutos a $72^{\circ} \mathrm{C}$. Os fragmentos amplificados foram separados em gel de agarose a uma corrente elétrica de $100 \mathrm{~mA}$. O gel foi corado com brometo de etídeo, descorado e fotografado. Os "primers" escolhidos foram os da "Operon Technologies", quais sejam, B6 (TGCTCTGCCC), B19 (ACCCCCGAAG), B8 (GTCCACACGG), G5 (CTGAGACGGA) e G11 (TGCCCGTCGT) pois apresentaram capacidade de gerar número médio de fragmentos de DNA amplificados polimórficos de alto peso, maior polimorfismo e alta repetibilidade dos resultados. Estes "primers" geraram 73 fragmentos de DNA amplificados, que são os "marcadores".

A análise dos dados morfológicos e agronômicos foi realizada com base em Steel \& Torrie (1960). Foram empregadas, na análise, a média das parcelas e as diferenças entre as médias dos tratamentos foram comparadas por meio do teste Tukey em 5\% de probabilidade. A análise dos dados moleculares foi baseada na presença ou ausência de bandas (1 ou 0 respectivamente) com o mesmo peso molecular. A partir dos géis obtidos foram construídas matrizes binárias. Os dados qualitativos e quantitativos obtidos da análise das características 
Tabela 1. Metodologia e padrões utilizados na análise das características morfo-agronômicas. Piracicaba, ESALQ, 1996.

\begin{tabular}{|c|c|c|c|c|c|c|}
\hline Características & Tipos & $\begin{array}{l}\text { Época } \\
\text { florada }\end{array}$ & $\begin{array}{c}\text { Ordem } \\
\text { frutificação }\end{array}$ & Equipamentos & Referências & $\begin{array}{c}\text { Número de } \\
\text { amostras }\end{array}$ \\
\hline $\begin{array}{l}\text { Forma dentes } \\
\text { do folíolo }\end{array}$ & $\begin{array}{c}\text { Aguda } \\
\text { Intermediária } \\
\text { arredondada }\end{array}$ & $1^{\mathrm{a}}$ & & visual & $\begin{array}{c}\text { Lemaitre \& } \\
\text { Linden (1968) }\end{array}$ & $\begin{array}{c}50 \text { folhas } \\
\text { maduras/parcela }\end{array}$ \\
\hline Cor da folha & $\begin{array}{l}\text { Verde clara } \\
\text { Verde média } \\
\text { Verde escura }\end{array}$ & $1^{a}$ & & visual & $\begin{array}{l}\text { Passos et.al. } \\
\text { (1994) }\end{array}$ & $\begin{array}{c}50 \text { folhas } \\
\text { maduras/parcela }\end{array}$ \\
\hline $\begin{array}{l}\text { Ângulo base do } \\
\text { folíolo }\end{array}$ & $\begin{array}{l}\text { Quantificado } \\
\text { (graus) }\end{array}$ & $1^{a}$ & & transferidor & $\begin{array}{c}\text { Lemaitre \& } \\
\text { Linden (1968) }\end{array}$ & $\begin{array}{c}50 \text { folhas } \\
\text { maduras/parcela }\end{array}$ \\
\hline $\begin{array}{l}\text { Razão compri- } \\
\text { mento/largura } \\
\text { do folíolo }\end{array}$ & Quantificado & $1^{a}$ & & régua & $\begin{array}{c}\text { Lemaitre \& } \\
\text { Linden (1968) }\end{array}$ & $\begin{array}{c}50 \text { folhas } \\
\text { maduras/parcela }\end{array}$ \\
\hline $\begin{array}{l}\text { Posição inflor. } \\
\text { em relação a } \\
\text { folhagem }\end{array}$ & $\begin{array}{c}\text { Acima } \\
\text { Abaixo } \\
\text { Acima e abaixo }\end{array}$ & $2^{a}$ & & visual & $\begin{array}{l}\text { Lemaitre \& } \\
\text { Linden (1968) }\end{array}$ & Todas as plantas \\
\hline $\begin{array}{l}\text { Tamanho do } \\
\text { cálice em } \\
\text { relação ao fruto }\end{array}$ & $\begin{array}{c}\text { Pequeno Médio } \\
\text { Grande }\end{array}$ & $2^{a}$ & $2^{\mathrm{a}}$ ou $3^{\mathrm{a}}$ & visual & $\begin{array}{l}\text { Passos et.al. } \\
\text { (1994) }\end{array}$ & 50 frutos/parcela \\
\hline $\begin{array}{l}\text { Proteção da } \\
\text { inflorescência } \\
\text { pelas folhas }\end{array}$ & $\begin{array}{l}\text { Pouco } \\
\text { Regularmente } \\
\text { Muito }\end{array}$ & $2^{a}$ & & visual & $\begin{array}{l}\text { Passos et.al. } \\
\text { (1994) }\end{array}$ & Todas as plantas \\
\hline $\begin{array}{l}\text { Ocorrência de } \\
\text { pescoço nos } \\
\text { frutos }\end{array}$ & Presente Ausente & $2^{a}$ & $2^{a}$ ou $3^{a}$ & visual & $\begin{array}{l}\text { Passos et.al. } \\
\text { (1994) }\end{array}$ & 50 frutos/parcela \\
\hline $\begin{array}{l}\text { Produção, nú- } \\
\text { mero e peso } \\
\text { dos frutos }\end{array}$ & Quantificado (kg) & todas & todas & balança & $\begin{array}{l}\text { Passos(1982); } \\
\text { Passos (1997) }\end{array}$ & $\begin{array}{c}\text { Frutos } \\
\text { comerciáveis }\end{array}$ \\
\hline $\begin{array}{l}\text { Teor de sólidos } \\
\text { solúveis dos } \\
\text { frutos }\end{array}$ & $\begin{array}{l}\text { Quantificado } \\
\text { (Graus Brix) }\end{array}$ & $3^{a}$ & $2^{a}$ ou $3^{a}$ & densitômetro & Passos (1982) & $\begin{array}{c}100 \mathrm{~g} \text { de } \\
\text { frutos/parcela }\end{array}$ \\
\hline $\mathrm{pH}$ dos frutos & Quantificado & $3^{a}$ & $2^{a}$ ou $3^{a}$ & peagâmetro & Passos (1982) & $100 \mathrm{~g} /$ parcela \\
\hline $\begin{array}{l}\text { Textura dos } \\
\text { frutos }\end{array}$ & Quantificado & $3^{a}$ & $2^{a}$ ou $3^{a}$ & $\begin{array}{l}\text { texturômetro } \\
\text { TAXT2 }\end{array}$ & $\begin{array}{c}\text { Ferreira } \\
(1981)\end{array}$ & 5 frutos/parcela \\
\hline $\begin{array}{l}\text { Cor externa e } \\
\text { interna dos } \\
\text { frutos }\end{array}$ & $\begin{array}{l}\text { Quantificado } \\
\text { (croma - c*) }\end{array}$ & $3^{a}$ & $2^{a}$ ou $3^{a}$ & $\begin{array}{l}\text { espectro- } \\
\text { fotômetro }\end{array}$ & Ferreira (1981) & 5 frutos/parcela \\
\hline
\end{tabular}

morfológicas e agronômicas foram transformados em matrizes binárias conforme o proposto por Bussab et al. (1990). A partir das matrizes binárias, formaram-se as matrizes de coeficientes de similaridade pelo método da similaridade qualitativa com o coeficiente de Jaccard (J). Para a formação dos dendogramas, as matrizes de coeficientes de similaridade foram analisadas pelo método do desempenho seqüencial de aglomeração hierárquica de grupos ("Sahn Clustering"), com o coeficiente do método da média aritmética entre pares não ponderados (UPGMA).

\section{RESULTADOS E DISCUSSÃO}

Três dendogramas foram organizados, um com os dados morfológicos e agronômicos, outro com os dados moleculares e o terceiro com os dados morfológicos, agronômicos e moleculares agrupados.

O dendograma obtido pela análise dos dados morfológicos e agronômicos, separou as cultivares Dover, Guarani e Princesa Isabel entre si e das cultivares Campinas e AGF 080. Os dados da ma- triz de coeficientes de similaridade indicaram que as cultivares Campinas e AGF 080 apresentaram $100 \%$ de similaridade. As cultivares Dover e Princesa Isabel demonstraram ser as mais semelhantes $(50 \%$ de similaridade), depois de 'Campinas' e 'AGF 080'. A cultivar Guarani ficou mais próximo de 'Campinas' e 'AGF 080' (40,5\% de similaridade) e mais distante de 'Dover' $(27,0 \%$ de similaridade) e 'Princesa Isabel' (23,7\% de similaridade). As cultivares Campinas e AGF 080 apresentaram 47,2\% de similaridade com 'Princesa Isabel' e 39,5\% de similaridade com 'Dover' (Tabela 2). 
Tabela 2. Coeficientes de similaridade entre cultivares com base em dados morfológicos e agronômicos (abaixo da diagonal) e de "marcadores" RAPD (acima da diagonal). Piracicaba, ESALQ, 1996.

\begin{tabular}{lccccc}
\hline \multicolumn{1}{c}{ Cultivares } & Dover & AGF 080 & Campinas & Princesa Isabel & Guarani \\
\hline Dover & & 0,586 & 0,586 & 0,750 & 0,467 \\
AGF 080 & 0,395 & & 1,000 & 0,606 & 0,548 \\
Campinas & 0,395 & 1,000 & & 0,606 & 0,548 \\
Princesa Isabel & 0,500 & 0,472 & 0,472 & \multirow{2}{*}{0,237} & 0,545 \\
Guarani & 0,270 & 0,405 & 0,405 & - \\
\hline
\end{tabular}

Tabela 3. Coeficientes de similaridade entre cultivares com base em dados morfológicos, agronômicos e de "marcadores" RAPD. Piracicaba, ESALQ, 1996.

\begin{tabular}{lccccc}
\hline \multicolumn{1}{c}{ Cultivares } & Dover & AGF 080 & Campinas & Princesa Isabel & Guarani \\
\hline Dover & 1,000 & & & & \\
AGF 080 & 0,478 & 1,000 & & & \\
Campinas & 0,478 & 1,000 & 1,000 & & \\
Princesa Isabel & 0,617 & 0,536 & 0,536 & 1,000 & \\
Guarani & 0,358 & 0,471 & 0,471 & 0,380 & 1,000 \\
\hline
\end{tabular}

A disposição das cultivares Campinas, Dover, Guarani, Princesa Isabel e AGF 080 no dendograma obtido, através dos dados moleculares, ficou igual ao dendograma obtido com os dados morfológicos e agronômicos, só diferindo pelos valores de similaridade. Graham et al. (1996) verificaram que o grau de similaridade entre as cultivares, quando os dados eram originários do estudo de 'pedigree', eram menores que o grau de similaridade quando os dados eram da análise de RAPD. Assim, concluiu que, com os dados de 'pedigree', há diferenças grandes entre as cultivares que na verdade são semelhantes quando o estudo utiliza dados de marcas RAPD. Um terceiro dendograma foi construído com os dados morfológicos, agronômicos e moleculares unidos das cinco cultivares e o resultado foi a mesma disposição de cultivares dos dendogramas obtidos quando os dados foram analisados separadamente, só diferindo pelos valores de similaridade (Tabela 3).

Gomes (1995) comparou linhagens de Sacharomyces cerevisae com dados moleculares e por características morfológicas. Em linhagens da indústria cervejeira os dendogramas obtidos de dados oriundos dos métodos de separação de cromossomos, eletroforese de proteínas e RAPD apresentaram a mesma formação de grupos. $\mathrm{O}$ autor também realizou análise conjunta dos dados, reunindo todos os métodos, e o dendograma obtido manteve a mesma formação de grupos.

A grande similaridade entre 'Dover' e 'Princesa Isabel' no dendograma construído com dados morfológicos e agronômicos, era esperada pela semelhança que as duas cultivares apresentaram entre si nos dados morfológicos. No entanto, não há informações sobre origem que mostre alguma relação entre o "pedigree" destas cultivares. A semelhança apresentada entre eles, pela análise dos dados moleculares, pode indicar que as diferenças morfológicas, expressas na planta, e as dissimilaridades do DNA, expressas pela análise de RAPD, proporcionaram resultados próximos. Isso pode ser aceito pela mesma disposição das cultivares no dendograma obtido pela análise das características morfológicas e agronômicas e no obtido pela análise molecular. Por outro lado, o "pedigree" das cultivares Guarani e Princesa Isabel são muito semelhantes, pois ambos têm $50 \%$ de alelos comuns do progenitor Alemanha. Além disso, o outro progenitor de 'Guarani' é o resultado do cruzamento entre 'Campinas' e 'Monte Alegre' e o outro de 'Princesa Isabel' é a cultivar Jundiaí que também tem como progenitores as cultivares Campinas e Monte Alegre. Ou seja, 'Guarani' e
'Princesa Isabel' têm os mesmos progenitores. No entanto, provavelmente devido ao processo seletivo a que foram submetidos os progenitores que deram origem a estas cultivares, resultou em cultivares bem diferentes. Assim, 'Princesa Isabel', apesar da origem diferente de 'Dover', é mais parecido morfologicamente e molecularmente com esta cultivar do que com 'Guarani' que, em termos de origem, é semelhante a 'Princesa Isabel', indicando que a seleção foi eficiente para alterar a composição genética nestas cultivares. Então, apesar de 'Dover' não ter semelhanças de origem com 'Princesa Isabel', tinha semelhanças morfológicas com esta cultivar, que refletiram em similaridade nas análises moleculares.

Os resultados comparados entre os métodos de caracterização com base em características morfológicas e agronômicas e o fundamentado em características moleculares, deste trabalho, demonstrou que a disposição das cultivares nos dendogramas foram iguais, só diferindo o grau de similaridade entre eles. Ferreira \& Grattapaglia (1996) comentam que "marcadores" morfológicos existem em menor número, o que limita a cobertura do genoma, além disso são específicos para um determinado tecido o que impede a sua determinação quando há apenas alguma parte vegetativa da planta disponível. Os 
"marcadores" moleculares têm a vantagem de em geral serem neutros em relação a efeitos fenotípicos com efeito mínimo ou nulo de epistasia ou pleiotropia. A desvantagem dos "marcadores" moleculares é a necessidade de alguns equipamentos, além de conhecimento próprio para o desenvolvimento da técnica, o que envolve, por exemplo, a determinação prévia de quais "marcadores" são os mais adequados à cultura que está sendo avaliada.

Considerando que a técnica de RAPD é relativamente barata, e que neste trabalho já foram detectados os "primers" B6, B8, B19, G5 e G11 como os mais eficientes para a cultura do morangueiro, podemos inferir que é viável utilizar o método de caracterização molecular, por análise de RAPD, como outra opção à caracterização morfológica atualmente utilizada. Novos trabalhos, com um número maior de "primers", poderá permitir uma caracterização e uma estimativa de distância genética mais precisa das cultivares do morangueiro e também possibilitará verificar possíveis diferenças entre as cultivares Campinas e AGF 080.

\section{AGRADECIMENTOS}

O presente trabalho foi realizado graças ao apoio da FAPESP, processo 96/ 1606-2, do CNPq, dos Departamentos de Horticultura e Genética da ESALQ/USP, e do produtor rural Claudemir Rodrigues Spinassi de Atibaia.

\section{LITERATURA CITADA}

BRINGHURST, R.S.; ARULSEKAR, S.; HANCOCK, J.F.; VOTH, V. Electrophoretic characterization of strawberry cultivars. Journal of the American Society for Horticultural Science, v. 106, n. 5 , p. 684-687, 1981.
BUSSAB W.O.; MIAZAKI, E.S.; ANDRADE, D.F. Introdução à análise de agrupamentos. São Paulo: ABE, 1990. 105 p.

CAMARGO, L.S. Resultados experimentais obtidos com o morangueiro. O Agronômico, v. 15, n. 3/4, p. 1-6, 1963.

CAMARGO, L.S. Novas variedades de morangueiro no estado de São Paulo. Piracicaba: ESALQ, USP, 1960. 48 p. (Tese doutorado)

CAMARGO, L.S.; PASSOS, F.A. Morango. In: FURLANI, A.M.C.; VIEGAS, G.P. (Ed.) $O$ melhoramento de plantas no Instituto Agronômico. Campinas: Instituto Agronômico, 1993, v. 1, cap. 11, p. 411-432.

FERREIRA, M.E.; GRATTAPAGLIA, D. Introdução ao uso de marcadores moleculares em análise genética. 2 ed. Brasília: EMBRAPACENARGEN, 1996. p. 220. (EMBRAPACENARGEN Documento 20).

FERREIRA, V.L.P. Princípios e aplicações da colorimetria em alimentos. Campinas: ITAL, 1981. 85 p. (ITAL Instruções Técnicas, 19).

GIDONI , D.; ROM, M.; KUNIK, T.; ZUR, M.; IZSAK, E.; IZHAR, S.; FIRON, N. Strawberrycultivar identification using Randomly Amplified Polymorphic DNA (RAPD) Markers. Plant Breeding, v. 113, n. 4, p. 339-342, 1994.

GOMES, L.H. Avaliação de quatro métodos para a caracterização de leveduras. Piracicaba: ESALQ, USP, 1995, 89 p. (Tese mestrado)

GRAHAM, J.; McNICOL, R.J.; McNICOL, J.W. A comparision of methods for the estimation of genetic diversity in strawberry cultivars. Theoretical and Applied Genetics, v. 93:, n. 3 p. 402-406, 1996.

HANCOCK, J.F.; LUBY, J.J. Genetic resources at our doorstep: the wild strawberries. Bio Science, v. 43, n. 3, p. 141-147, 1993.

HOWARD, C.M.; ALBREGTS, E.E. 'Dover' Strawberry. HortScience, v. 15, n. 4, p. 540, 1980. LEMAITRE, R.; LINDEN, R. Le frasier à gros fruits. Description et identification de variétes. Gembloux: J. Duculot, S.A., 1968. 234 p.

LEVI, A.; ROWLAND, L.J.; HARTUNG, J.S. Production of Reliable Randomly Amplified Polymorphic DNA (RAPD) Markers from DNA of Woody Plants. HortScience, v. 28, n. 12, p. 1188-1190, 1993.

NEHRA, N.S.; KARTHA, K.K.; STUSHNOFF, C. Nuclear DNA content and isozyme variation in relation to morphogenic potential of strabberry (Fragaria x ananassa) callus cultures. Canadian Journal of Botany, v. 69, n. 2, p. 239-244, 1991.
PARENT, J.G.; PAGÉ, D. Authentification des 13 cultivars de fraisier du programme de certification du Québec par 1'analyse d'ADN polymorphe amplifié au hasard (RAPD). Canadian Journal of Plant Science, v. 75, n. 1, p. 221-224, 1995.

PASSOS, F.A. Caracterização de clones nacionais e introduzidos de morangueiro (Fragaria $x$ ananassa Duch.), visando o uso imediato na horticultura e o melhoramento genético. Piracicaba: ESALQ, USP, 1982, 116 p. (Tese mestrado)

PASSOS, F.A. Influência de sistemas de cultivo na cultura do morango (Fragaria $x$ ananassa Duch.) Piracicaba: ESALQ, USP, 1997, 105 p, (Tese doutorado)

PASSOS, F.A.; GRIDI-PAPP, I.L.; CAMARGO, C.E.O.; CHIAVEGATO, E.J.; DALL'ORTO, F.A.C.; NAGAI, H.; deGODOY, I.J.; FAZUOLI, L.C.; VEIGA, R.F.A. Descritores mínimos para o registro institucional de cultivares: MORANGO. Campinas: IAC, 1994. 8 p. (IAC Documentos, 40). SANTOS, J.B. Emprego de marcadores moleculares no melhoramentode plantas. Horticultura Brasileira, Brasília, v. 12, n. 2, p. 282-286, 1994.

SCOTT, D.H.; LAWRENCE, F.J. Strawberries. In: JANICK,J. \& MOORE, N.M. Advances in fruit breeding. Indiana: Purdue University Press. 1975. p. 71-92.

SJULIN, T.; DALE, A. Genetic diversity of North American strawberry cultivar. Journal of the American Society for Horticultural Science, v. 112, n. 2, p. 375-385, 1987.

STEEL, R.G.D.; TORRIE, J.R. Principles and procedures of statistics with special references to the biological sciences. New York: Mc. Graw Hill book Co. Inc., 1960. 481 p.

SWARTZ, H.J.; GALLETTA, G.J.; ZIMMERMANN, R.H. Field performance and phenotypic stability of tissue culture-propagated strawberries. Journal of the American Society for Horticultural Science, v. 106, n. 5, p. 667-673, 1981.

WILLIAMS J.G.K.; KUBELIK, A.R.; LIVAK, K.J.; RAFALSKI, J.A.; TINGEY, S.V.; DNA polymorphisms amplified by arbitrary primers are useful as genetic markers. Nucleic Acids Research, v. 18, n. 22 , p. $6531-6535,1990$. 